Meta

Journal des tradlucteurs

Translators' Journal

\title{
Tools for Terminology
}

\section{Peter Gawn}

Volume 35, numéro 2, juin 1990

URI : https://id.erudit.org/iderudit/002833ar

DOI : https://doi.org/10.7202/002833ar

Aller au sommaire du numéro

Éditeur(s)

Les Presses de l'Université de Montréal

ISSN

0026-0452 (imprimé)

1492-1421 (numérique)

Découvrir la revue

Citer cette note

Gawn, P. (1990). Tools for Terminology. Meta, 35(2), 452-455.

https://doi.org/10.7202/002833ar

Ce document est protégé par la loi sur le droit d'auteur. L’utilisation des services d'Érudit (y compris la reproduction) est assujettie à sa politique d'utilisation que vous pouvez consulter en ligne.

https://apropos.erudit.org/fr/usagers/politique-dutilisation/
Cet article est diffusé et préservé par Érudit.

Érudit est un consortium interuniversitaire sans but lucratif composé de l'Université de Montréal, l'Université Laval et l'Université du Québec à Montréal. Il a pour mission la promotion et la valorisation de la recherche. https://www.erudit.org/fr/ 


\section{BLOC-NOTES}

\section{TOOLS FOR TERMINOLOGY}

The Canadian government has had an official terminology service for 34 years, since 1953, the same year that saw the creation of the F.I.T. But the origins of organized terminology in Ottawa, Canada's capital, in so far as they can be traced, go back further than that -100 years further, to 1852 , the year that marked the creation of the Institut canadien-français d'Ottawa - the French-Canadian Institute. The handful of government translators of the 1850 s found a welcome in the Institute, and together they started work towards improving the French found in the government's legislative and administrative texts, and increasing the number of publications available in French.

Seventy years later, in 1921, the translators incorporated themselves into an association, and included among their objectives the production of technical glossaries, and greater uniformity in terminology used in translating government texts. The method they adopted was discussion in open meetings, which were regularly reported in Le Droit, the local French newspaper. Topics covered in the early days included the workings of a typewriter, legal jargon, and Parisian French. A lexicon committee was set up in 1923, and bilingual vocabularies began to appear, on stencilled pages, to the tune of over 100 issues. Later, in 1950, the translators association began publishing a Bulletin, largely devoted to bilingual vocabularies and, finally, in 1953, it created a Lexicology Centre, manned by some 50 volunteers who devoted one night a month to the compilation of a central card index for which all government translators were invited to submit the results of their terminological research.

It was this Centre, taken over in the same year by the Secretary of State Translation Bureau, that evolved into what is now the Terminology Directorate, of which I am currently the Director. My distant predecessor, he worked alone, was responsible for making bilingual cards, drafting terminological bulletins and guidelines, gathering useful documentation, answering requests for advice over the telephone, and looking after the production and distribution of the Centre's publications. He was a real one-man band!

If I have taken these few minutes to relate the origins of our terminology service it is because this mini-history illustrates the methods used in terminol- ogy and mentions the tools that, until very recently, were all that were available to the terminologist. Let me review them.

The methods included identifying the correct terms, achieving uniformity, collating the resuits, making the terminology available and verifying that the approved terminology was used. The tools were minutes of meetings, file cards, useful documentation, stencilled vocabularies followed by printed publications, and the telephone. Committee work and input from translators were key strategies for success. In fact, as our history shows, there were then no terminologists as such: it was the translators who recognized the need to pool their knowledge and resources for their mutual benefit - a sort of self-help, bootstrap operation which transposed into a collective activity something that had previously been an individual preoccupation.

This last point is important and needs to be kept in mind by the professional terminologist of today, who can only too easily lose sight of the utilitarian need that a terminology service must respond to. And this prompts another reflection: the needs that a terminology service aims to meet vary with the political and administrative context that gave rise to the creation of the service and that conditions its evolution. Not all services have the same vocation, not all term banks - the tool I am going to discuss next stock the same kind of funds. Two examples from Canada serve to support this contention. Termium, the Linguistic Data Bank of the government of Canada, was established specifically to foster standardization of the French and English terminology used by the departments and agencies that compose the public service of Canada, and to prevent a proliferation of divergent terminologies. The term bank of the French Language Office of the Province of Quebec, on the other hand, serves to support the principal mission of the Office, which is to ensure that French replaces English as the language of work and communication in all public and private bodies operating within the Province of Quebec. Two very different mandates, and consequently two different although not greatly dissimilar methodologies and structures. And the same divergence exists with the other major term banks: the stated purpose of each does not correspond exactly to the mandate of any of the others.

Let us look at term banks for a few minutes. These are the large, complex and costly computer data bases that are used to stock, sort and retrieve 
words and varying amounts of supporting textual information. They are expensive, not only in terms of hardware, software and maintenance but also for the resources - terminologists and support staff required to feed them. Few organizations can justify the cost, which, to maintain the computer part alone easily exceeds one million dollars a year. When one adds the development costs, it seems certain that no other organization would want to embark on the creation of a new bank comparable to the existing big five. Once a termbank is established, keeping it up to date is an onerous task. This year we expect to add new records and modify or cancel existing records a the rate of about 4,000 a week. We have come a long way from the 50 volunteers working one night a month on the original card index. But we are also a long way from having a bank that is current, that keeps up with the tens of thousands of new terms entering the language every year, and that contains nothing but correct, verified data.

Let's forget about the problem of the giant term banks for the moment and look at what a terminologist does. We have about 80 staff terminologists working in our organization. They work in teams, each terminologist being responsible for a given subject field. Assignments include research on lengthy projects in specific subject areas corresponding to needs in the translation sector, and which often result in the publication of glossaries or vocabularies; research on lists of terms taken from translator's texts; and research on isolated terms, the equivalents for which are requested by telephone. Terminologists may also be called upon to participate in terminology standardization committees, to prepare articles on terminological questions for publication, or to study specific concepts in order to propose new or more appropriate denominations.

Terminologists must be familiar not only with their fields of research (including available documentation, subject-field structure and the names of specialists for consultation purposes) but also with the principles governing terminological research. New data must be entered on records for input into the TERMIUM Bank and data already in the Bank must be periodically screened for updating and completion.

Other activities that terminologists undertake include: periodic updates of the subject-field classification system, preparation and revision of research guidelines for terminologists and of guides for users, work on technical aspects of the Bank in cooperation with systems analysts, and liaison with other organizations and individuals active in the field.

The result of all this work is made available through three main channels: the terminology bank, the telephone consultation service and published glossaries and lexicons. To give you some idea of the demand for terminology, we expect this year that online querying of the term bank will total about 800 thousand interrogations, that we will respond to 80 thousand telephone queries, that we will research another 50 thousand terms sent to us in writing rather than by phone, and that we will complete for publication some 50 vocabularies. One final statistic - if we were to print out all the terminology records in the term bank on $81 / 2 \times 11$ sheets, we would have a pile of paper 70 feet high - so please do not ask us for printouts!

Now, as you may recall, in my mini-history $\mathbf{I}$ itemised the methods used by our forerunners, and also the tools they worked with. The methodology is basically unchanged: finding and agreeing on the right terms, collating the results, making them available, and verifying that the agreed terms are used. With the exception of the last point, verification that the correct terms are used, this methodology still applies. The big difference of course is in how the work is done, the tools that are used, rather than in what is done.

When we start thinking about how to do terminology we enter the realm of data processing, of computers and all their ancillary equipments. Basically, the terminology methodology comprises four activities: first, searching for terms and collecting them; second, identifying the correct or acceptable terms; third, storing, collating, sorting the terms; and fourth, distributing the terms. The technical problems related to the third and fourth activities - storage and distribution - have largely been resolved, although improvements are constantly being made as the technology advances. I deliberately stressed earlier the huge size and cost of major term banks, and the astonishing equivalent volume of paper pages they contain. In order to make this mass of information more readily available without the need for on-line access to the host computer we have had our entire terminology database transferred on to a single compact disk, a CD-ROM. We expect to be marketing the compact-disk version of Termium some time in 1988.

Transfer of term banks on to compact disks will greatly facilitate access for translators working with microcomputers. As I mentioned in the presentation I made at last year's panel in Cleveland, we are pushing ahead with research into a translator's workstation. Preliminary specifications should be finalized soon. This study is being carried out at the Canadian Workplace Automation Research Centre, located just north of Montreal. We expect that the workstation will allow the translator to do dictionary look up on a split screen and automatically paste the selected word into the ongoing translation.

Although the preliminary specifications for the workstation will probably not include a machinetranslation facility, we are pursuing our activity in this area too. Our current experiments are with the LOGOS system, now being used to translate texts dealing with dataprocessing. The development team has been provided with a computer tape of the portion of the terminology bank covering dataprocessing terms, for building into the system. Mr. Moïse Levy of our Montreal office will be present at the Saturday morning panel in order to provide more information on this project. And, of course, as you know, our 
METEO system continues faithfully to generate translations of weather bulletins as part of the Canadian weather forecast distribution network.

Now, these last few minutes have been a bit of a digression. My topic is Tools for Terminology, and what I want to concentrate on now is tools required to help terminologists, rather than ways of making terminology available to users of it. Much of terminology work is extremely painstaking and time consuming. Finding terms, sorting them into classifications, establishing which are the appropriate terms, getting consensus among interested organizations - these are the areas where terminologists need help. This is particularly important in a service like ours where because of our mandate and because of the assistance we must provide to our own translators, we have to come up with the right term. And this allows me to embark on another digression. Canada is a member of the fairly loose association of French-speaking countries known as la Francophonie. One of the activities that the heads of state of the participating countries agreed to at their first meeting last year in Paris was concerned with the contribution that the industries de la langue, language industries, could make to the collectivity. One concretc accomplishement was the creation of the Réseau international de néologie et terminologie - an international network for neology and terminology. Estimates vary as to the rate of growth of the language, primarily the English language, particularly in science and technology. Figures quoted vary between 10 thousand and 40 thousand new words a year. This proliferation poses an incredible problem for linguists, especially translators, trying to find equivalents in other languages. It is hoped that the new Network, which was able to present its first vocabularies at the second Francophone Summit in Quebec last month, will coordinate the work being done in the major French-speaking entities - France. Belgium, Quebec and Canada - and provide the infrastructure for making new terms or newly-coined terms available quickly to the other French-speaking countries.

Many of these countries are part of what has been called the Third World, the South, or lessdeveloped nations. This fact is an element that has to be taken into account in language planning, since the use of computers is much less widespread in those countries, therefore term banks, data bases CD-ROMs and so on are not too relevant. Traditional distribution methods in paper dictionaries are still essential, together with first-level technical applications such as microfiches. We are therefore continuing an active publication program, and we have recently completed an updated microfiche set of our term bank.

Mention of neology, finding or creating words to denominate in one language things or concepts invented in another language, brings me back to the basic terminological activity, establishing the corpus of words, with their definitions or descriptions, appropriate to a particular domain. Existing databases enable the terminologist to identify and locate perti- nent documentation which can then be scrutinized. What we need now is software programs to facilitate the scanning of texts and to extract the target terminology with its context and source. Once a terminologist has found the words he needs, he has to enter them into the term bank. This is still largely a manual operation. If we had more-or-less intelligent optical character readers, a lot of the clerical work could be done automatically, thus freeing the terminologist for more analytical, judgemental tasks. None of the existing major term banks has an imaging capability, the possibility of storing illustrations, with captions, in the memory. Pictorial representation of all kinds can be of enormous help, both in identifying terminology, and in providing the user of a term bank with help in choosing the right word.

What the terminologist is waiting for now is in fact the application of existing technology, and particularly the adaptation of artificial intelligence, to the searching and sorting phase of his work, together with greater mechanisation of the collating and dataloading aspect. With the use of artificial intelligence, term banks could become expert systems for the user, searching the right term to fit the particular context and proposing it for incorporation into the translation, or even into an original composition. What do I have in mind? Let's say you are working on a text and need the medical term for inflammation of the eyelids. You would give the system an instruction, in plain language, such as: "Find the medical term for inflammation of the eyelids". In the twinkling of an eye, the word, in this case blepharitis, would come up on the screen, ready to be pasted into the text.

Use of more advanced and more accessible technology would also allow our organization, and others sharing the same concern, to be more effective in ensuring that approved terms are in fact used in official documents. This type of verification, which was relatively easy in the more constrained world that I related in my mini-history, is almost impossible today with the tools presently available. We are certainly entering a period, however, where this capability, like the others I have evoked, will become a reality, providing the resources are made available for it.

I started my address with a mini-history of terminology in Ottawa. It would be tempting to try to close these remarks with a mini-forecast. I shall not do so, for the simple reason that the introduction of new computer programs and devices, and the conceiving and developing of new ways of applying them to language problems, including terminology, all happen so fast and in so many different places that it is almost a full-time job trying to keep informed. I cannot claim to be well enough informed to draw an accurate picture of the future. What is clear, of course, is that whatever can be automated will be, in one way or another. and that the increasing automation of terminological activity will accelerate and refine the distribution of terms to those who need them.

I still have in mind a picture of the 50 translator volunteers who in the Ottawa of the 1950 s devoted 
one night a month to building up the central card index from suggestions sent in by their colleagues. To me this is a telling image, and a salutary reminder to those of us working in terminology that not only do we have a most appreciative clientele for our services, but that the same clients can also be prime suppliers of terms for the termbank.

And so we pursue, with today's tools, and will do so with those of tomorrow, the self-help, bootstrap, operation that began over 60 years ago. And we do so with the same thoroughness and the same enthusiasm.

PETER GAWN

Terminology Directorate, Secretary of State, Ottawa 